\title{
Spatial Characteristic of Coal Mining in Kutai Kartarnegara Regency, East Kalimantan Province
}

\author{
Nasruddin \\ Geography Department, Universitas Lambung Mangkurat \\ Email: nasruddin_luthfie@unlam.ac.id.
}

\begin{abstract}
Coal mining activities in Kutai Kartanegara Regency conducted in an open way. Number IUP announced by the Directorate General of Mineral and Coal, Ministry of Energy and the results reconciliation of Mineral Resources IUP with the 210 status Clean and Clear (C \& C). The purpose of the study is to identify the characteristics and patterns of coal mining in Kutai Kartanegara Regency based landform units in order to see the distribution pattern of its spread. The method used the construct maps of landforms unit in Kutai Kartanegara Regency derived from Satellite Imagery Landsat 7 ETM + in 2012, A sheet of study area Indonesia Map, Geological Map, Soil type and field surveys Map using ArcGIS 9.3 facilities. The results showed that the characteristic of the coal mining in Kutai Kartanegara Regency is implemented by way of an open mining. With the status of the production details 151 IUP (72\%) and the exploration 59 IUP (28\%). Condition of the land of post coal mining in some areas showed low implementation of the rules set by the government for land reclamation, thus causing in high environment such as erosion, flooding and landslides. Unit landform with majority in the coal mining activities is wavy tectonic cluster. The cause of the pattern of coal mining activity tend to cause factors of the position / location of relatively shallow or have undergone a process of outcrops to the surface between 0-30 meters, easy access from the mine to the port. The research result recommendations is conducted anticipation program from the dangers of impact that occurs as erosion and sedimentation, water quality and soil (land potential), The licensing selection strictly refer to the legislation and in depth learning to identify a variety of potential post-mining land to be developed on the post-mining unit of the shape according to the character of the land.
\end{abstract}

Keywords: Characteristic, Pattern of Coal Mining

\section{Introduction}

Coal mining activities in Kutai Kartanegara Regency is one the region with the highest number of mining activities across Indonesia. This condition must be increased in line with the growing strength of regional regulatory system in order to control some of the potential mineral resources and coal (minerba) that legislation give an authority with law in the regions through the Regional Autonomy Law No. 22, 2002 to pass the exploitation as part of local revenue. Acquisition value budget (APBD) Kutai Kartanegara Regency over the last 3 years is one of the highest regency budget (APBD) in Indonesia 5.656 trillion in 2011 and in the year 2012 reached 6.8 trillion further in 2013 to reach 7.5 trillion. Kutai Kartanegara Regency economic structure in general is dominated by the mining activities and quarrying which $88.05 \%$.

The approach of landform unit in looking at the characteristics and patterns of coal mining in Kutai Kartanegara regency is very positive, it is because of a few cases that the mining lands in managing post-mining coal still casuistic. Thus the approach of landform units is expected to provide a solution in view of the phenomenon of coal mining activities at the level of wide scope areas and homogeneous. Landform unit is one approach method for identifying regions. Landform unit is the shape and characteristic of the appearance of the earth's surface (Verstappen, 1983; Suharsono, 1988; Desaunettes, 1977; Suratman and Dibyosaputro, 1995). Landforms approach has been widely applied in many ways, especially in the field of planning for land resources. Sartohadi and Rahardjo (2004) explained that the approach geomorphological 
can be applied in mapping semidetil ground level. Physiographic approach to land mapping by applying geomorphological analysis can classify land units with a high degree of homogeneity $(>72 \%)$.

\section{Method}

The research method is arranging landform map units in Kutai Kartanegara Regency based on processing some data including Landsat satellite 7 ETM + In 2012, A sheet of study area Indonesia Map, Geological Map, Soil type and field surveys. The objective is to facilitate the classification of landforms in the study of geomorphology, is by simplifying complex Earth's surface into units that have a similarity in the nature and character using ArcGIS 9.3.

\section{Result and Discussion}

Coal mining activities in Kutai Kartanegara Regency generally carried out with an open pit mining 12 of 27 landforms found in Kutai Kartanegara Regency. The number of companies with the production status IUP $151(72 \%)$ and the status of the exploration IUP $59(28 \%)$ or as a whole is 210 IUP.

Table 1. Coal mining landform unit based on Activity and Activity Status Coal Mining Company

\begin{tabular}{|c|c|c|c|c|c|c|c|}
\hline \multirow[b]{2}{*}{ No } & \multirow[b]{2}{*}{ Code } & \multirow[b]{2}{*}{ Landform } & \multicolumn{3}{|c|}{ Status of IUP C\&C } & \multicolumn{2}{|c|}{$\%$ IUP C\&C } \\
\hline & & & $\begin{array}{c}\text { Eks- } \\
\text { ploration }\end{array}$ & $\begin{array}{c}\text { Pro- } \\
\text { duction }\end{array}$ & Total & $\begin{array}{c}\text { Eks- } \\
\text { ploration }\end{array}$ & $\begin{array}{c}\text { Pro- } \\
\text { duction }\end{array}$ \\
\hline 1 & A.1.1.2.2 & Backswamp & 3 & 5 & 8 & 38 & 63 \\
\hline 2 & G.2 & Peat & 4 & 4 & 8 & 50 & 50 \\
\hline 3 & M.1.2 & Sand Beach & 0 & 1 & 1 & - & 100 \\
\hline 4 & M.2.2 & Mud Tidal Plat & 1 & 7 & 8 & 13 & 88 \\
\hline 5 & T.10.1 & Wavy Peneplain & 1 & 0 & 1 & 100 & - \\
\hline 6 & T.11.1 & Plain Flat Tectonic & 5 & 6 & 11 & 45 & 55 \\
\hline 7 & T.11.2 & Plain Wavy Tectonic & 29 & 100 & 129 & 22 & 78 \\
\hline 8 & T.11.3 & Plain Tectonic Swell & 5 & 20 & 25 & 20 & 80 \\
\hline 9 & T.12.1 & Hills Tectonic & 1 & 0 & 1 & 100 & - \\
\hline 10 & T.5.3 & Hogback Complex & 3 & 5 & 8 & 38 & 63 \\
\hline 11 & T.8 & Monoclinic & 1 & 0 & 1 & 100 & - \\
\hline 12 & T.9.1 & Hills Parallel Fold & 6 & 3 & 9 & 67 & 33 \\
\hline \multicolumn{3}{|c|}{ Total } & 59 & 151 & 210 & 28 & 72 \\
\hline
\end{tabular}

Source: Mining Advocacy Network (Jatam) East Kalimantan, 2011 and Directorate General Minerba Ministry ESDM Jakarta, 2011

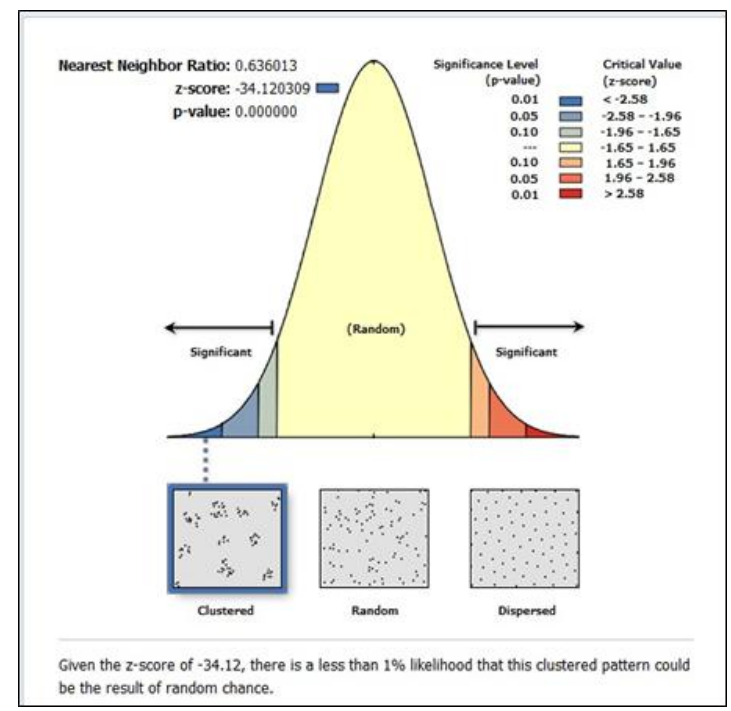

Figure1. Average Nearest Neighbor Summary Pattern Coal Mining in Kutai Kartanegara Regency 
Pattern mining coal in Kutai Kartanegara Regency had a pattern majority cluster in landform plain tectonic wave IUP 129 or $61 \%$ and the rest is distributed to other landforms. Several things can cause the cluster IUP on the plain landform tectonic which position / location of relatively shallow coal or have undergone a process of outcrops to the surface between 0-30 meters, in addition to easy access by road from the mine to the port. Conditions on the other landforms inversely relative to other landform the main factor is the relative access because is only supported by the river access and interior region position of Kutai Kartanegara Regency.

\section{Conclussions}

Based on the explanation above can be concluded several things: (1) characteristics of coal mining in Kutai Kartanegara Regency are implemented by way of an open pit mine. The number of coal mining activities 210 IUP with production detail status IUP 151 (72\%) and the exploration IUP 59 ( $28 \%$ ), (2) the condition of post-mining coal in some areas showed low implementation of the rules set by the government for land reclamation, so that part of the area has been transformed into a post-mining land with environmental problems such as erosion, flooding and landslides, (3) unit landforms majority in the coal mining activities plain tectonic wave with clusterr, and (4) the cause of cluster coal mining activities due to factors of the position / location of relatively shallow or have undergone a process of outcrops to the surface that is $0-30$ meters, easy access from the mine to transport.

\section{References}

Desaunettes, J. R. (1977). Catalogue of Landform for Indonesia. Example of Physiographic Approach to Land Evaluation for Agricultural Development. Prepared for The Land Capability Appraisal Project at The Soil Research Inst., Bogor-Indonesia.

Directorate General Minerba Ministry ESDM Jakarta. (2011). Result Reconcilitation IUP (Clean and Clear). Jakarta

Mining Advocacy Network (Jatam) East Kalimantan. (2011). Area of Coal Mining Inventaritation in Kutai Kartanegara Regency. Samarinda City, East Kalimantan Province.

Sartohadi, Junun and Rahardjo, Noorhadi. (2004). Relationship of Landform and Soil on Landform Approach. Journal of Gama Sains VI (1) 2004.

Suharsono, Prapto. (2000). Landform Identification and Imagery Interpretation for Geomorphology. Yogyakarta: Geography Faculty, Gadjah Mada Unversity.

Suratman and Dibyosaputro, Suprapto. (1995). Terrain Evalution and Classification. Training on Land Resource Evaluation V July $1^{\text {th }}-31^{\text {th }} 1995$. Yogyakarta: Geography Faculty, Gadjah Mada University.

Verstappen, H., Th. (1983). Apllied Geomorphology, Journal of Elsevier Science Publishers. Co,Amsterdam. 